\title{
MURDEKORRESPONDENT AADU TOOMESSALU
}

Akadeemilise Emakeele Seltsi parim murdekorrespondent Aadu Toomessalu on sündinud 23. okt. 1916. aastal Saaremaal Orissaare rajoonis Purtsa külas mõisa teenijatüdruku pojana. Koolis hakkas A. Toomessalu käima kümneaastaselt ja õppis hea eduga. Hoolimata heast edasijõudmisest, pidi A. Toomessalu pärast viienda klassi lõpetamist koolist lahkuma, sest ema majanduslik olukord ei võimaldanud poega edasi koolitada. Nii tuli viieteistkümne-aastasel poisil hakata teenima endale ülalpidamist. Ta käis suviti koos onuga taludes ehitustöödel, talvel aga tegi kodus puusepatööd.

Soov end edasi arendada ning oma teadmisi täiendada ei kadunud A. Toomessalul siiski. Olgugi et sissetulek oli väga väike, leidis ta aegajalt võimalusi peamiselt loodusteaduse- ja ajaloo-alaste raamatute muretsemiseks. Loodusteadus oli juba õpilaspõlvest peale A. Toomessalu lemmikharrastuseks. Ta soetas endale kohaliku taimestiku herbaariumi, püüdes ühtlasi kindlaks teha iga taime rahvapärast nimetust. Putukate kogus, mida A. Toomessalu pidevalt täiendas, esinevad nüüd peaaegu kõik Saaremaal leiduvad liblikate liigid. Eriti suurt huvi tundis A. Toomessalu aga oma rahva ajaloo ja kultuuriloo vastu. See õhutaski teda etnograafiliste, rahvaluuleliste ja keeleliste materjalide kogumisele. Ta vestles inimestega ja pani kirja oma tähelepanekud tööst vabal ajal, pühapäeviti ja hilistel õ̉htutundidel. Nõukogude korra kehtestamisega Eestis 1940. aastal paranesid järsult töö- ja elutingimused. Ka kultuurialane töö, eriti keelelise, rahvaluulelise ja etnograafilise ainestiku kogumine muutus nüüd palju intensiivsemaks. Nüüd asus A. Toomessalu erilise innuga kultuuriloolise materjali kogumisele keele, rahvaluule ja etnograafia alal. Seda jätkab ta kolhoositöö kõrval nüüdki, võttes elavalt osa ka ühiskondlikust tööst. Tänu oma tegevusele rahvapärase kultuuriainestiku, eriti keelelise materjali kogumisel, on ta, alates käesolevast aastast Orissaare rajooni kultuurhariduse osakonna lektoritegrupi liikmeks.

\section{Keeleainestiku kogumine}

Murdematerjalide kogumisele asus A. Toomessalu 1940. aastal. Ta on töötanud keeleainestiku kogumisel suure entusiasmiga ning on kirja pannud ligi 3000 lehekülge teksti ja tähelepanekuid Saaremaa murrakuist ja üle 500 sedeli sõnavara. Eriti intensiivselt on ta töötanud viimastel aastatel. Alates 1949. aastast tänaseni on temalt saabunud 1772 lehekülge kaastööd ja ligi 250 sõnasedelit. A. Toomessalu tööd keeleainestiku kogumisel on järgmised:

1. Vanad jutud

2. Karjapidamisest

3. Vanaaegsest põllupidamisest $\quad 87 \mathrm{lk}$. 

4. Endisaegsest meeste käsitööst
5. Muistsetest pidudest ja pühadest
6. Muistsed söögid ja joogid
7. Vanaaegsed ehitused
8. Metsa kasutamisest endistel aegadel
9. Tuli ja valgustus minevikus
10. Saun
11. Endisaegse eesti elamu sisustus
12. Sepp
13. Tõrva-, pigi- ja söeasjandusest
14. Talurahva ülestõus von Sengbuschi vastu Karja mõisas aastal 1905
15. Pöide murde grammatika peajooni
16. Käsikivi
17. Tuulikud
$169 \mathrm{lk}$.
$192 \mathrm{lk}$.
$99 \mathrm{lk}$
$264 \mathrm{lk}$.
$109 \mathrm{lk}$.
$68 \mathrm{lk}$
$59 \mathrm{lk}$
$95 \mathrm{lk}$.
$71 \mathrm{lk}$.
$64 \mathrm{lk}$.

18. Mitmesugust sõnavaralist materjali ligi 500 sõnasedelit

A. Toomessalu poolt kogutud murdematerjal on väga väärtuslik keeleliselt. Valdava enamiku, 2202 lehekülge sellest moodustavad murdetekstid. Need on Saaremaa kesk- ja idaosa vanemate elanike jutustused ja kirjeldused, mis on üles kirjutatud sõnasõnalt kohalike elanike jutustuste järgi murdekeeles. Nõnda leidub neis rohkesti ehtsaid rahvapäraseid väljendeid ja kõnekäände, näit. lastu tuluke ja lainat leib, neid pole ikka kauvaks (KT 64, 11), kase puu sööd seisid köige kauvam elus, söuksed männi- ja kuuse sööd nee surid ruttu äe (KT 64, 13), silmad lõid oort tuld (KT 64, 29), see oli ikka siis kui möisa saks su kurat ja kergu öpetaja su jumal olid (KT 65, 8), leib just kui tümakakk (KT 126, 42), löö tümaga puul suud kinni kuida suul muidu äi seisa (KT 126, 42), sepp sii sündis süsi suus, raijeraud ja pihid püus (KT 124, 2) jne. Kõik tekstid on kirja pandud erilises transkriptsioonis, mille aluseks on eesti kirjakeele kirjutamisviis, kuid mis mõningate täiendustega annab võrdlemisi täpselt edasi hääldamise iseärasusi. Murdetekstid on üles kirjutatud paljudest küladest Saaremaa kesk- ja idaosas. Nendes on rikkalikult andmeid saarte murrakute erijoonte kohta foneetilises ja morfoloogilises struktuuris, lauseehituses ja sõnavaras. Eri kohtadest kirjapandud tekstid näitavad kohalikke erinevusi. Etnograafilised kirjeldused sisaldavad rohkesti rahvapärast terminoloogiat (tõrva- ja söeasjanduse, sepatöö, puutöö jne. kohta), näit. käre tähendab tõrva sisaldavat männipuu tükikest, pekikord - koore all olev kord puul, sakk - känd, mis ühes juurtega on maa seest välja võetud, it's - paksu teraga raieraud, kilksima - taguma, naelusk - aukudega raud naelapeade löömiseks jne. Nii pakuvad nad ohtrasti ainestikku ka Saaremaa sōnavara kohta. Stiililt erinevad tekstid üksteisest. Neis leiame kirjelduste tõsist asjalikkust, muhedat huumorit, kuid vahel ka robustset naturalistlikku ütlemisviisi, sest täpse üleskirjutamise nõudel on säilitatud jutustajate väljenduse omapära. Need otseselt rahvasuust üleskirjutatud murdetekstid on oma lopsaka stiiliga rahva ehtsa kõnekeele näited. Keeleuurijale on need usaldatavaks materjalikoguks, allikaks saarte murrete tundmaõppimisel.

Rikkalikku etnograafilist materjali sisaldavad tema tööd «Sepp», «Saun», «Tuli ja valgustus minevikus», «Tõrva-, pigi- ja söeasjandusest», «Vanaaegsed ehitused», «Endisaegse eesti elamu sisustus», «Vanaaegsest põllupidamisest», «Käsikivi», «Tuulikud» jne. Nendes töödes leidub mitmesuguseid andmeid eesti töötava rahva ainelise kultuuri kohta peamiselt möödunud sajandi lõpust. Kõik need kirjeldused on varustatud selgitavate jooniste ja skeemidega. Sealjuures on joonised tehtud täpselt, neile on märgitud joonistatud eseme mõõdud, üksikosade nimetused, eseme asukoht, 
päritolu jne. Töös «Vanaaegsed ehitused» on palju jooniseid Saaremaa vanadest taluehitistest. On antud elu- ja kõrvalhoonete põhiplaanid, ristining põiklõiked, samuti üksikasjalised joonised ehitusdetailidest jne. Töös «Endisaegse eesti elamu sisustus» aitavad sisu selgitada joonised mitmesugustest mööbliesemetest, mis möödunud sajandil olid saartel üldiselt tarvitusel. Töös «Sepp» on antud sepikoja ots- ja külgvaade, läbilõige ning pōhiplaan, lisatud joonised tööriistadest, valmissepistest jm. Nende murdetekstide heaks küljeks on kirjelduse konkreetsus. Neis ei räägita üldiste sõnadega mingist abstraktsest esemest, vaid kirjeldatakse teatud konkreetset hoonet, tööriista või muud. Nõnda on esitatud materjal usaldatav ka etnograafiliselt.

Ainelise kultuuri kõrval on murdetekstides vastavalt teemale jälgitud ka sotsiaalseid vahekordi endisaegses külas. Näit. «Endisaegse eesti elamu sisustuse» puhul näidatakse vahet rikkama taluniku ja vaese sauniku elamu sisustuses. Töös «Sepp» kirjeldatakse sepa, sotsiaalset seisundit endisaegses külas. Töös «Saun» kõneldakse sotsiaalsest kihistumisest ja klassivõitlusest endises külas ning esitatakse masendav pilt sauniku viletsusest.

Rohkesti rahvaluulelist materjali sisaldavad murdetekstid «Vanad jutud», «Muistsetest pidudest ja pühadest», samuti $\propto$ Saun», «Sepp» jt. Neis leidub vanasõnu ja kõnekäände, näit. must kui süsi, tõrv ja tubakas on tervisele eed, nii sammu kauvaks kui õle tuld, läks kui tule viija jne., samuti kombeloolist ainestikku. Ajaloolise sisuga on Toomessalu tekst «Talurahva ülestõus von Sengbuschi vastu Karja mõisas aastal 1905», mis ühe kohaliku elaniku jutustuse järgi valgustab seda sündmust. Töös on ära toodud ka rahvalaul «Kui aasta number sai tuhat üheksasada kuus», milles kõneldakse karistussalkade tegevusest ja ülestõusust osavõtjate vanglasse viimisest Riiga.

A. Toomessalu kõige silmapaistvam töö on 1951. aasta märtsikuus valminud «Pöide murde grammatika peajooni». See 757-me leheküljeline töö on murdekorrespondentide suurimaks tööks seni üldse. Grammatika jaguneb kolme ossa: häälikuõpetus, vormiõpetus ja lauseõpetus. Neile lisanduvad murdetekstid, 13 seotud jutustust. Iga käsiteldav nähtus selgitatakse rikkaliku rahvakeelse näitematerjali varal, mis koosneb üksikuist lauseist. Häälikuõpetus annab ülevaate Pöide murraku häälikulisest koos. seisust. Pöide ala Saaremaal läbistavad mitmete keelenähtuste leviku piirid, näit. ô-hääliku esinemise piir Saaremaal ja aa muutumise piir oa-ks. A. Toomeșsalu on hoolega jälginud mõlemat keelenähtust ning koostanud kummagi nähtuse leviku kohta kaardi.

Eriti põhjalikult on grammatikas käsitletud vormiõpetust, mis võtab enda alla suurema osa tööst. Seitsmekümne kolme nimisõna ja kuuekümne kahe pöördsõna muutmise kohta ja nende sõnade tarvitamisest lauses on toodud rohkesti näiteid. Iga käsitletava sõna jaoks on koostatud käänamisvõi pööramistabelid, kus on näidatud sõna muutelõppe ning tarvitamist eri põlvkondade keeles.

Lauseõpetuse osa on kõige lühem, ainult 11 lehekülge. Siin esitatakse näitelauseid küsitluskava alusel. See ebaproportsionaalsus on tingitud asjaolust, et süntaks on olnud seni kõige vähem uuritud ala eesți keeleteaduses. Ka vastav küsitluskava on väike.

Grammatika lõppu on lisatud keelejuhtide elulood, kellelt on kirjutatud töös kasutatud keelenäiteid, ja murdesõnade register. See rikkaliku rahvakeelse näitematerjaliga varustatud töö sisaldab väärtuslikke andmeid saarte murrete grammatilise struktuuri kohta. Töös jälgitakse nii vanema kui keskmise ja noorema põlvkonna keelepruuki. Nii võime järeldada, missugused murde erijooned püsivad ja missugustel on kaotendents. Näit. käskiva kõneviisi ains. 2. pöörde eitava kõne lõpp -g näitab kaoten- 
dentsi, ta esineb ainult vanema pōlvkonna keeles: Äe ming täna koost äe! (Ära mine täna kodust ära!) Ainult vanema pōlvkonna keelt iseloomustab samuti näit. oa esinemine $a a$ asemel: moa, ei soa. Teisalt näeme, et murrakus on kujunemas mõned uued jooned, mis puuduvad vanemal põlvkonnal, näit. rohke si-lõpu tarvitamine mitmuse osastavas. Tähtsamate murdejoonte kohta on esitatud ülevaatlikud kaardid. A. Toomessalu «Pöide murde grammatika peajooned» on kirjeldav grammatika, ta annab põhjaliku ülevaate ühe eesti murraku grammatilisest struktuurist antud momendil. Sellised grammatikad aitavad paremini mõista eesti keele struktuuri, soodustavad keele arenemise sisemiste seaduspärasuste uurimist, mis on keeleteaduse peaülesandeid, nagu ütleb seltsimees Stalin oma geniaalses teoses «Marksism ja keeleteaduse küsimused».

Keelelise ainestiku kogumise kõrval on aga A. Toomessalu pidevalt töötanud ka rahvaluulelise ja etnograafilise materjali kogumisel.

\section{Rahvaluule kogumine}

A. Toomessalu on kogunud rahvaluulelist ainestikku paljudest kohtadest Saaremaal, töötades viimastel aastatel peamiselt Pöide piirkonnas.

ENSV TA Riiklikus Kirjandusmuuseumis on A. Toomessalu kogutud materjale 1550 lehekülge. Sisulise kokkuvõtte järgi on selles 1850 numbrit kirjapanekuid. Toomessalu poolt kogutud rahvaluulematerjal on väga mitmesugune. Rohkesti on rahvajutte - umbes 300 numbrit. Palju on ka vanasõnu ja kõnekäände - 325, mõistatusi - 100 , rahvalaule ïle 100, mänge - 100 jne. Arvukalt on kirjeldusi ja teateid rahvakommetest. Hulgaliseit on ka nõndanimetatud õiguslikku rahvatraditsiooni. Esineb ka etnograafilisi · kirjeldusi karjandusest, põllundusest, tõrvapõletamisest, lubjaahjudest jne.

A. Toomessalu kirjapanekud rahvaluule alal on nagu keelelisedki materjalid täpsed ning usaldatavad, on varustatud kõigi vajalike andmetega (kellelt, kus ja millal üles kirjutatud jne.). Ta on siingi hoolikalt silmas pidanud keelelist külge ning teinud kirjapanekud kohalikus murdes.

\section{Etnograafilise materjali kogumine}

Ajavahemikus $1946-1951$ on A. Toomessalu saatnud ENSV TA Eesti Rahva Muuseumile ligi 700 lehekülge kaastööd. Suurema tööna tuleks esile tõsta kirjeldust «Õu ja hooned», mis käsitleb Saaremaa taluhoonete ehitamist ning nende asetust õues möödunud sajandi lõpul. Mahukamatest töödest tuleks veel nimetada: «Aiad ja väravad», «Tubakas ja selle tarvitamine endisel ajal», «Põllundusest», «Jahindusest», «Puutööst», «Rahvapärane kaubandus», «Paadiehitus», «Eesti rahvapäraseist looma arstimisviisidest» jne. Peale nende on paarkümmend vähemat tööd (3 kuni 25 lk.) mitmesugustel teemadel vastuseks Eesti Rahva Muuseumi poolt esitatud küsimustele. Tööd on varustatud väga heade selgitavate joonistega. A. Toomessalu poolt kogutud etnograafiline materjal on samuti kui keeleline ja rahvaluuleline täpne ning usaldatav.

\section{A. Toomessalu tööviisist}

Peaaegu kõik A. Toomessalu tööd on õieti vastuseks esitatud küsimustele. Etnograafilist materjali on ta kogunud vastavalt Teaduste Akadeemia Eesti Rahva Muuseumi küsitluskavadele. Ka rahvaluule alal on ta küsimused läbi 
töötanud küsitluskavade alusel. Murdematerjale on A. Toomessalu kogunud saadud juhendite põhjal samuti süstemaatiliselt. Asudes tööle uue teema juures on ta alati pöördunud Akadeemilise Emakeele Seltsi poole näpunäidete saamiseks, millistele küsimustele tuleks osutada erilist tähelepanu. Nii on ta töötanud aktuaalsete, päevakorras olevate probleemide uurimisel, lahendades need ülesanded, mis on vajalikud vastava teadusharu uurimistöös. J. V. Stalini keelealaste tööde ilmumine on tekitanud pöörde keeleteaduses. Kogı keeleteaduslik töö Eesti NSV-s reorganiseeritakse stalinliku keeleõpetuse printsiipide kohaselt. Ka murdeainestiku kogumine ja küsitluskavade koostamine toimub nende põhimõtete alusel. Nii on J. V. Stalini tööd avaldanud suurt mõju ka A. Toomessalule. Ta töötab uute küsitluskavade järgi, on tutvunud stalinliku keeleteaduse põhimõtetega Tartus korraldatud seminaris ja kirjanduse kaudu. See kõik on tõstnud tema töö edukust viimaseil aastail.

A. Toomessalu poolt kogutud rikkalik ainestik Saaremaa murrakute, rahvaluule ja ainelise kultuuri kohta on väärtuslikuks panuseks meie kultuuri varasalve.

A. UNIVERE 